\title{
ASUHAN KEPERAWATAN PADA PASIEN DENGAN DENGUE HAEMORRAGIC FEVER (DHF) DI RUANG JAYANEGARA RSU. Dr. WAHIDIN SUDIROHUSODO MOJOKERTO
}

\author{
Raudhatul Jannah $^{1}$, Dwiharini Puspitaningsih ${ }^{2}$, Eka Diah Kartiningrum ${ }^{3}$ \\ ${ }^{1,2,3}$ D3 Keperawatan STIKes Majapahit Mojokerto
}

\begin{abstract}
Dengue Hemorrhagic Fever (DHF) still becoming health problem in Indonesia, complication DHF disease usually assosiated with severe, prolonged shock, heavy bleeding. This case study arined to carry out nursing care patients with DHF in Jayanegara room of RSU Dr. Wahidin Sudirohusodo Mojokerto.Results of study found different complaints participant on participant 1 said fever, nausea vomiting, abdominal pain. In participant 2 said heartbum, weakness, bleeding joint, bleeding gum. The diagnosis in both participants were lack of fluid volume. Interventions performed on patients 1 management of oral intake, nutritition management, encouraging patients bedrest, collaborated medical teams, monitoring vital signs, monitor blood test result. On Participant 2 monitoring bleeding, oral intake, nutritition management, encouraged patients to bedrest, collaborated with medical team, monitored vital signs, monitor blood test result. The $3 \times 24$ hour evaluation results for participants 1 and 2 showed did not feel nausea, vomiting and no spontaneous bleeding. intervention with nursing problem of lack fluid volume, there increase in platelets, and patient's fluid needs were met, problem resolved. Participants DHF can experience plasma leakage and bleeding resulting a decrease in platelets. To replace fluid lost due to plasma leakage, can be done motivate participants fluid needs, including recommending drinking plenty of water.
\end{abstract}

Keywords: Care, Nursing, DHF, Volume, Fluid

\section{A. PENDAHULUAN}

Indonesia Penyakit Demam Berdarah Dingue atau Dengue Hemoragic Fiver (DHF) masih menjadi masalah pokok kesehatan didunia dan juga di Indonesia. Penyakit DBD dapat muncul sepanjang tahun dan dapat menyerang seluruh kelompok umur. Penyakit ini berkaitan dengan kondisi lingkungan dan perilaku masyarakat. (KEMENKES RI, 2018). Penyakit Demam Berdarah Dengue (DBD) disebabkan oleh virus Dengue dari genus Flavivirus, famili Flaviviridae dan mempunyai 4 jenis serotipe, yaitu: Den-1, Den-2, Den-3, dan Den-4. Penderita yang tinggal di daerah endemis dapat terinfeksi lebih dari 1 serotipe selama hidupnya (Tomia, dkk, 2016).

Virus dengue menempati tingkat yang sangat tinggi diantara penyakit di Asia. Asia menempati urutan pertama dalam jumlah penderita demam berdarah dengue di tiap tahunnya. Indonesia sebagai Negara dengan kasus demam berdarah dengue tertinggi di Asia Tenggara (Andarmoyo, Handoko, 2013). Keempat serotipe virus dengue telah ditemukan di berbagai wilayah di Indonesia (Tomia, dkk, 2016). Hampir sepanjang tahun penyakit DBD ini selalu ditemukan di seluruh Indonesia terutama pada awal musim penghujan (Sucipto, dkk, 2015). Di kotaMojokerto kasus penderita demam berdarah dengue (DBD) terjadi selama 5 tahun berturut-turut dari tahun 2013 sampai 2017 (DinasKesehatan Kabupaten Mojokerto, 2017). 
Secara global jumlah kasus demam berdarah dingue di Indonesia tahun 2017 sebanyak 68.407 penderita dengan jumlah kematian sebanyak 493 jiwa dan CFR 0,75\%. Di jawa timur tahun 2017 terdapat 7.254 penderita dengan Jumlah kematian sebanyak 104 jiwa dan CFR 1,43\% (KEMENKES, 2018). Sedangkan menurut laporan Dinas Kesehatan Mojokerto tahun 2017 terdapat 221 penderita, dengan rincian lakilaki sebanyak 111 penderita dan perempuan 110 penderita.

Hasil yang didapatolehpetugaskesehatan di RSU Dr. WahidinSudirohusodo Kota MojokertopenderitaDengue Haemorragic Fever (DHF) padatahun 2019 bulanjanuari di ruangJayanegarasebanyak 23 penderita. Dan di bulanfebruaritanggal 1-5 sebanyak 9 penderita.

Dengue ditularkan melalui gigitan nyamuk yang mengandung virus dingue. Dengan adanya genangan air bersih menjadi tempat perkembangbiakan larva nyamuk aedes aegypti, dan kurangnya pengetahuan masyarakat yang menyebabkan seringnya terjadi epidemis dengue, (Malela dalam Umboh, 2016). Sebagian besar penderita menunjukkan gejala demam yang tidak khas. Tanda dan gejala demam dengue yang klasik antara lain berupa demam tinggi yang menimbulkan masalah keperawatan hipertermi yang terjadi secara mendadak, sakit kepala, nyeri di belakang bola mata (retro-orbital), rasa sakit pada otot dan tulang.Mual muntah, badan lemas yang menyebabkan munculnya masalah keperawatan kekurangan volume cairan.Sakit tenggorokan, ruam kulit makulopapuler. berarti nyeri otot dan tulang yang dialami penderita yang menyebabkan demam dengue di kenal sebagai demam patah tulang (breakbone fever) (Soedarto, 2012). Komplikasidengue Haemorragic fever (DHF) biasanya berhubungan dengan syok yang berat dan memanjang dan perdarahan berat. Pemberiancairan yang berlebihan selama fase kebocoran plasma dapatberakibat yang berujung pada gagal nafas, dapat terjadi gangguan elektrolit/metabolik: hipoglikemia, hiponatremia, hipokalsemia, atau terkadang hiperglikemia (Tjokro prawiro, 2015).

Berdasarkan penelitian yang dilakukanoleh (Siregardalam Liza, 2015), bahwa pencegahan dan penanggulangan Dengue Haemorragic Fever (DHF) sangat tergantung kepada partisipasi masyarakat. Upaya pemutusan rantai nyamuk dengan fogging focussertapemberantasannyamuk(PSN).,Tindakankeperawatan yang bisa di lakukan untuk mengatasi hipertermi yaitu menurunkan suhu tubuh pasien, yang pertama dengan cara kompres hangat pada kedua ketiak, lipatan paha, kedua lutut bagian dalam paling banyak pembuluh darah, sehingga sel saraf akan segera member sinyal kehipotalamus untuk menurunkan suhu tubuh (Sodik indalam susilo, 2016). Penggunaan kompres hangat dapat mencengah pasien untuk menggigil. Kompres hangat merangsang vasodilatasi sehingga mempercepat proses evaporasi dan konduksi yang dapat menurunkan suhu tubuh (Sodikin dalam Permatasari, 2012). Mual muntah yang menyebabkan kekurangan volume cairan, tindakan keperawatan yang bisa dilakukan yaitu mempertahankan intake dan autput yang adekuat, rehidrasi oral, sepertimemberikan minum jus buah ataus usus upaya tidak terjadi dehidrasi (Nugrahajati, 2012)

\section{B. TINJAUAN PUSTAKA}

\section{Konsep Dasar Dengue Hemoragic Fever (DHF)}

\section{a. Definisi Dengue Hemoragic Fever(DHF)}

Penyakit Demam Berdarah Dengue (DBD) adalah penyakit yang disebabkan oleh virus Dengue yang tergolong Arthropod-Borne Virus, genus Flavivirus, dan famili Flaviviridae. DBD ditularkan melalui gigitan 
nyamuk dari genus Aedes, terutama Aedes aegypti atau Aedes albopictus (KEMENKES RI, 2018).

Virus dengue dapat menginfeksi manusia melalui gigitan nyamuk genus Aedes terutama Ae. aegypti dan Ae. Albopictus. Keduanya merupakan vektor penting yang mampu menyebarkan penyakit DBD pada host (manusia). Nyamuk Ae. aegypti dan Ae. albopictus adalah nyamuk tropis yang berasal dari Afrika Tengah dan biasanya ditemukan pada habitat yang berbeda. Perbedaan habitat kedua jenis genus Aedes merupakan salah satu mekanisme untuk mempertahankan koeksistensi geografis. Ae. Aegyptilebih menyukai daerah perkotaan dan domestik, yaitu di sekitar tempat tinggal manusia dan cenderung berkembang biak di kontener buatan, sedangkan Ae. Albopictusbanyak ditemukan pada daerah pedesaan dan lebih banyak berkembang di habitat alami, tetapi ditemukan pula pada tempat penampungan air. Honorio et al. menjelaskan bahwa Ae. aegypti dan Ae. albopictus merupakan spesies yang cenderung berkembang biak yang sama dan sering ditemukan dalam kontener buatan. Spesies nyamuk ini hidup hidup berdampingan dalam wadah buatan manusia di pemukiman perkotaan, pinggiran kota dan pedesaan di daerah tropis dan subtropis (Tomia, dkk, 2016)

Vector utama penyakit DHF adalah nyamuk aedes Aegypti(didaerah perkotaan) dan Aedes Albopticus(di daerah pedesaan). Nyamuk yang menjadi vector penyakit DHF adalah nyamuk yang menjadi terinfeksi saat mengigit manusia yang sedang sakit dan viremia (terhadap virus dalam darahnya). Virus berkembang dalam tubuh nyamuk selama8-10 hari terutama dalam kelenjar liurnya dan jika nyamuk ini menggigit orang lain maka virus dengue akan dipindahkan bersama air liur nyamuk. Dalam tubuh manusia, virus ini akan berkembang selama 4-6 hari dan orang tersebut akan mengalamai sakit Dengue Haemorragic Fever. Virus Dengue memperbanyak diri dalam tubuh manusia dan berada dalam darah selama satu minggu. Orang yang didalam tubuhnya terdapat virus dengue tidak semua akan sakit Dengue Haemorragic Fever (DHF), ada yang mengalami demam ringan dan sembuh dengan sendirinya atau bahkan ada yang sama sekali tanpa gejala sakit, tetapi semuanya merupakan pembawa virus Dengue selama satu minggu, sehingga dapat menularkan kepada orang lain diberbagai wilayah yang ada nyamur penularnya. Sekali terinfeksi, nyamuk menjadi infektif seumur hidupnya (Widoyono, 2011).

Tanda dan gejala penyakit Dengue Haemorragic Fever (DHF) dengan diagnosa klinis dan laboratorium menurut Wijaya \& Putri (2013) adalah sebagai berikut:

1) Diagnosa Klinis

a) Demam tinggi mendadak $2-7$ hari $\left(38-40^{\circ} \mathrm{C}\right)$

b) Manifestasi perdarahan dalam bentuk: Uji Turnequetpositif, petekie, purpura, ekomosis, perdarahan konjungtiva, epistaksis, perdarahan gusi, hematemesis, melena, dan hematuri.

c) Rasa sakit pada otot persendian.

d) Pembesaran hati (Hepatomegali).

e) Renjatan (syok), tekanan nadi turun menjadi $20 \mathrm{mmHg}$ atau kurang, tekanan sistolik $80 \mathrm{mmHg}$ atau lebih rendah . 
f) Gejala klinik lainnya yang sering menyertai yaitu anoreksia, lemah, mual muntah, sakit perut, diare, dan sakit kepala.

2) Diagnosa laboratories

a) Trombositopenia (jumlah trombosit kurang dari $100.000 / \mu \mathrm{L}$ )

Hemokonsentrasi ( peningkatan hematokrit $\geq 20 \%$ )

\section{Konsep Dasar Dengue Hemoragic Fever (DHF)}

Menurut Wijaya dan Putri (2013), asuhan keperawatan pada pasien Dengue Haemorragic Fever, yaitu:

\section{a. Pengkajian Data}

1) Indentitas Klien

Terdiri dari nama, alamat, umur, status, diagnosa medis, tanggal masuk rumah sakit, keluarga yang dapat dihubungi, catatan kedatangan, nomor rekam medik.

2) Keluhan Utama

Biasanya pasien datang ke RS dengan keluhan demam lebih dari 3 hari, tidak mau makan, terdapat bintik merah pada tubuh.

3) Riwayat Kesehatan Sekarang

a) Suhu tubuh meningkat sehingga menggigil yang menyebabkan sakit kepala

b) Tidak nafsu makan, mual muntah, sakit saat menelan, lemah

c) Nyeri otot dan persendian

d) Konstipasi dan bisa juga diare

e) Mukosa mulut kering, perdarahan gusi, lidah kotor

f) Batuk ringan

g) Mata terasa pegal, sering mengeluarkan air mata (lakrimasi), fotofobia

h) Ruam pada kulit

i) Perdarahan pada kulit/petekie, ekimosis, hematoma, dan perdarahan lain seperti epitaksis, hematemesis, hematoria, melena.

4) Riwayat Penyakit Dahulu

a) Riwayat aktivitas sehari-hari

b) Pola hidup

5) Riwayat Kesehatan Keluarga

a) Adanya penderita DHF dalam keluarga

b) Riwayat aktivitas sehari-hari

c) Pola hidup

6) Pemeriksaan Umum

a) $\mathrm{KU}:$ cukup/buruk

b) Kesadaran : compomentis/apatis/somnolen/sopor/koma.

c) Tanda-tanda vital:

(1) Tensi : menurun (N: 110/70-120/80 mmHg)

(2) Nadi : takikardi (N: 60-100x/menit)

(3) Pernafasan : Normal atau meningkat (N: 16-24x/menit)

(4) Suhu: meningkat (N: $36,5-37,5{ }^{\circ} \mathrm{C}$ ) 


\section{METODEPENELITIAN}

Desain yang digunakan pada penelitian ini ada studi kasus untuk mengeksplorasi masalah asuhan keperawatan pada pasien dengan Dengue Haemorragic Fever (DHF) Di Ruang Jayanegara RSU Dr. Wahidin Sudirohusodo Mojokerto. Pengumpulan data ini dilakukan dengan cara melakukan asuhan keperawatan yaitu pengkajian, analisa data, diagnosa keperawatan, intervensi keperawatan, implementasi keperawatan dan evaluasi. Pengkajian keperawatan ini meliputi pertanyaan dan pemeriksaan fisik untuk mendapatkan data subjektf (DS) dan data objektif (DO).Uji keabsahan data dalam studi kasus ini menggunakan empat data utama yaitu klien, keluarga klien, status medis dan perawat ruangan yang berkaitan dengan masalah yang diteliti . sumber data utama tidak hanya dari klien tapi keluarga klien, perawata dan status medis juga diperlukan untuk menentukan validitas dari data yang sudah diperoleh dari klien. Cara penulisan publikasi ilmiah adalah dengan mencantumkan nama lengkap penulis beserta NIM dan nama-nama pembimbing sebagai co-author, nama prodi dan institusi dengan format publikasi (Puspitaningsih, dkk, 2018).

\section{HASILPENELITIAN}

Penelitian studikasus ini dilakukan di RSU Dr. Wahidin Sudiro husodo Mojokerto di ruang jaya negara kelas 2 dengan diagnosa Dengue Haemorragic Fever(DHF).

Hasil pengkajian tanggal 18 Maret 2019 jam 10.04 WIB keluhan yang muncul pada responden 1 adalah demam 5 hari naik turun, tinggi saat malam hari, mual, pada pemeriksaan fisik npasient tampak lemas, membran mukosakering, akral dingin, tanda-tanda vital TD 100/70 mmHg, Nadi 94x/menit, suhu $36,8{ }^{\circ} \mathrm{C}$, RR 20x/menit, pada pemeriksaan laboratorium tanggal 17 Maret 2019 didapatkan penurunan Trombosit 83.000/uL. Pada pengkajian tanggal 21 Maret 2019 jam 04.45 WIB keluhan yang muncul pada responden 2 adalah demam 5 harinaikturun, tinggi saat malam hari, terjadi perdarahan spontan di gusi saat dirumah, nyeri seluruh tubuh, pasien tidak bisa tidur, pada pemeriksaan fisik pasien tampak lemas, nyeri ulu hati saat dilakukan pemriksaan palpasipada abdomen, membran mukosa kering, akral dingin, nyeri kepala, tanda-tanda vital TD 90/60 mmHg, Nadi 104x/menit, suhu $36,5^{\circ} \mathrm{C}$, RR $22 \mathrm{x} /$ menit, pada pemeriksaan laboratorium di dapatkan pemenurunan trombosit 14.000/ul.

Diagnosa yang muncul pada kedua partisipan adalah kekurangan volume cairan berhubungan dengan kehilangan cairan aktif. Berdasarkan teori proses perjalanan penyakit Dengue Haemorragic Fever hingga menimbulkan masalah keperawatan diawali dengan saat virus dengue masuk kedalam tubuh, maka virus ini akan mengalami kontak dengan antibody dan virus akan bereaksi dengan antibody serta terbentuknya kompleks antigen antibodi. Aktivasi C3 dan C5 akan dilepas C3a dan C5a. Kemudian terjadi peningkatan permeabilitas di dinding pembuluh darah dan perembesan plasma keluar menuju ektravaskuler sehingga menyebabkan kekurangan volume cairan (Wijaya \& putri, 2013). batasan karakteristik yang ada peningkatakan frekuensi nadi, penurunan pengisian vena, membran mukosa kering, kelemahan, penurunan tekanan darah, muncul diagnosa keperawatan kekurangan volume cairan (Keliat, dkk, 2018).

Tujuan intervensi pada pasien yang dilakukan yaitu setelah di lakukan tindakan keperawatan selama $3 \times 24$ jam di harapkanpada patisipan 1 keadaan umum cukup, akralhangat, nadidalambatas normal $80-100 \mathrm{x} /$ menit, trombositdalambatas (30- 
100.000/ul), hematokritdalambatas normal (37-52), tanda-tanda vital dalambatas normal. Sedangkan tujuan intervensi pada reponden 2 setelah dilakukan tindakan keperawatan selama 3x24 jam di harapkan keadaan umum cukup, tidak ada perdarahan spontan, akral hangat nadi dalam batas normal (80-100x/menit), trombosit dalam batas (30-100.000/ul), hematokrit dalam batas normal, tanda-tanda vital dalam batas normal.

\section{E. PEMBAHASAN}

Berdasarkan intervensi keperawatan yang dilakukan hampir semua tindakan keperawatan sama dari manajemen asupan oral untuk meningkatkan keseimbangan cairan dan mencegah komplikasi akibat kadar cairan yang abnormal atau yang tidak diharapkan. Manajemen asupan nutrisi bertujuan untuk membantu atau menyediakan asupan makanan dan cairan dalam diet yang seimbang. Memantau intake dan output bertujuan untuk mengetahui balance cairan. Ajarkan keluarga dan pasien tentang tanda dan gejala syok bertujuan untuk meningkatkan keadekutan perfusi jaringan untuk pasien yang mengalami gangguan volume intravaskuler yang berat. Bedrest, bertujuan untuk membantu memproduksi lebih banyak trombosit dan mempercepat penyembuhan. Didalam Perencanaan keperawatan tidak semua ada diteori ada beberapa perencanaan yang di lakukan yaitu kolaborasi dengan tim medis, pemberian HE kepada pasien dan keluarga tentang tanda dan gejala Dengue Haemorragic Fever dan penanganannya.

Berdasarkan implementasi yang dilakukan terhadap pasien pada perkembangan kedua partisipan mengalami peningkatan. Implementasi yang dilakukan pada partisipan 1 di hari pertama pasien mengatakan masih mual, akral dingin, dan lemas, hasil Laboratorium tanggal 17 Maret 2019 menunjukkan trombosit 83.000/ul. Pada implementasi kedua pasien mengatakan sudah tidak mual, masih pusing dan makan terasa pahit, hasil Laboratorium tanggal 19 Maret 2019 menunjukkan trombosit 14.000/ul rencana transfusi Thrombocyte Concentrate (TC). pada implementasi ke tiga pasien membaik, mengatakan batuk dan nyei uluhati, keadaan umum cukup, mendapatkan transfusi 5 kolf Thrombocyte Concentrate (TC) , dan hasil observasi TTV dalam batas normal, dan hasil laboratorim tanggal 20 Maret 2019 menunjukkan trombosit 30.000/ul. Implementasi yang di lakukan pada partisipan 2 di hari pertama pasien mengatakan nyeri sendi, badan lemas, akral dingin, dan mukosa bibir kering, dan tidak ada perdarahan spontan, hasil laboratorium tanggal 21 Maret 2019 trombosit 46.000/ul, transfusi Thrombocyte Concentrate (TC) 5 kolf. Implementasi kedua pasien ada perkembangan pasien mengatakan badan tidak nyeri, TTV dalam batas normal, hasil laboratorium tanggal 22 Maret 2019 trombosit 64.000/ul. Implemetasi ketiga pasien membaik pasien mengatakan tidak lemas, membran mukosa lembab, ttv dalam batas normal dan hasil laboratorium tanggal 23 Maret 2019 105.000/ul.

Evaluasi yang dilakukan selama $3 \times 24$ jam pada evaluasi hari pertama kondisi partisipan 1 pasien mengatakan masih mual, tampak lemah, pasien tampak makan nasi 2 sendok, akral dingin, TTV :TD 100/70 $\mathrm{mmHg}$, suhu $37,5^{\circ} \mathrm{C}$, Nadi 80x/menit, RR 22x/menit. Pada partisipa 2 pasien mengatakan lemas, akral hangat, mukosa bibir kering, makanan tampak tidak habis, tidak ada perdarahan spontan, TD 100/70 mmHg. Suhu 36,8, nadi 88x/menit, RR 20x/menit, dengan hasil trombosit 46.000/ul. Pada evaluasi hari kedua pada partisipan 1 pasien mengatakan pusing, mulutnya pahit dan tidak mual lagi, pasien menghbiskan makanan $1 / 2$ porsi TD $100 / 60 \mathrm{mmHg}$. Suhu 36,4, nadi 80x/menit, RR 20x/menit, akral dingin, trombosit 14.000/ul mengalami 
penurunan dan evaluasi kedua pada partisipan 2 pasien mengatakan lemas berkurang, akral hangat, mukosa bibir kering, TD $110 / 70 \mathrm{mmHg}$. Suhu $36,5^{\circ} \mathrm{C}$, nadi $80 \mathrm{x} / \mathrm{menit}$, RR 20x/menit hasil laboratorium trombosit 64.000/ul. Pada evaluasi ketiga pada partisipan 1 mengatakan nyeri uluhati dan batuk, keadaan umum cukup, nafsu makan baik transfusi 5 kolf Thrombocyte Concentrate (TC) tanggal 19/03/2019 jam 21.00 WIB , hasil laboratorium trombosit 30.000/ul dan pada patisipan 3 pasien mengatakan pusing, akral hangat, mukosa bibir lembab, dan TTV dalam batas normal, hasil laboratorium trombosit 105.000/ul

\section{F. PENUTUP}

Evaluasi pada kedua partisipan setelah dilakukan tindakan keperawatan selama 3x24 jam pada dengan masalah keperawatan kekurangan volume cairan didapatkan kedua partisipan mengalami perbaikan kondisi yaitu ditandai dengan tidak adanya demam atau suhu dalam batas normal, , tidak ada mual muntah, padapemeriksaanfisik partisipan keadaan umu m cukup, membranmukosalembab, akralhangat, pemeriksaan laboratorium didapatkan trombosit dalam batas 30100.000/ul. Evaluasi pada partisipan 2 tidak adanya perdarahan spontan pada gusi.

Diharapkan peran penting bagi perawat untuk memberikan HE kepada pasien dan keluarga agar tindakan yang akan dilakukan lebih maksimal. Bagi perawat pasien memiliki pengetahuan tentang tindakan keperawatan dengan Dengue Haemorragic Fever (DHF) dan diharapkan keluarga mampu mengatasi pada anggota keluarga lainnya sebagai pertolongan pertama sebelum dilakukan tindakan medis. Bagi institusi peendidikan Memberikan kemudahan dalam pemakaian sarana prasarana yang merupakan fasilitas bagi mahasiswa untuk mengembangkan ilmu pengetahuan dan ketrampilannya melalui praktek klinik dan pembuatan laporan. Bagi peneliti selanjutnya yang inginmelakukanpenelitiandengankasus yang sama disarankan mampu meningkatkan asuhan keperawatan yang lebih berkualitas, memberikan tingkat pelayanan keperawatan dengan memodifikasi tindakan keperawatan tanpa meninggalkan konsep dan etika keperawatan

\section{G. DAFTAR PUSTAKA}

Budijanto., Didik. 2017. Data dan Informasi Profil Kesehatan Indonesia. Jakarta: Kementrian Kesehatan RI.

Dinkes Kota Mojokerto. 2017. Profil Kesehatan Kota Mojokerto. Mojokerto: Dinas Kesehatan Kota Mojokerto.

Keliat, Budi Anna., Mediani, Suzana., Tahlil, Teuku. 2018. NANDA-I Diagnosa Keperawatan Definisi dan Klasifikasi Edisi 11. Jakarta: EGC.

Nugrahajati, P. 2012. Thypus DBD Malaria Pencegahan dan Penanggulangannya. Jakarta: Wahyu Media.

Umboh I.V., Kndou D.G., Kepel J.B. 2016. Hubungan Antara Pengetahuan dan Sikap Tentang Program 3M Plus Dengan Kejadian DBD di Wilayah Kerja Puskesmas Ranotana Weru Kota Manado. https://ejournalhealth.com/index.php/ikmas/article/view/73/71(diakses tanggal 12 Februari 2019 jam 19.49 WIB).

Puspitaningsih, D., Kartiningrum, E,D., Puspitasari, W. 2018. Buku Panduan Studi Kasus Prodi D3 Keperawatan. LPPM Sekolah Tinggi Ilmu Kesehatan 
Majapahit.

Permatasari, kariana, I., Hartini, S. \& Bayu Muslim, A. 2013. Perbedaan Efektifitas Kompres Air Hangat dan Kompres Air Biasa Terhadap Penurunan Suhu Tubuh pada Anak dengan Demam di RSUD. Tugurejo Semarang. http://ejournal.stikestelogorejo.ac.id/index.php/ilmukeperawatan/article/view/ $\underline{126 / 151}$ (diakses pada tanggal 12 februari 2019 jam 12.34 WIB).

Soedarto. 2012. Demam Berdarah Dengue. Jakarta: Sagung Seto.

Sucipto, Teguh. 2015. Faktor-fakor yang Mempengaruhi kejadian penyakit Demam Berdarah Dengue (DBD) dan jenis SerotipeVirus Dengue di Kabupaten Semarang. Jurnal Kesehatan Lingkungan Indonesia Vol. 14 No. 2. https://media.neliti.com/media/publications/4907-ID-faktor-faktor-yangmempengaruhi-kejadian-penyakit-demam-berdarah-dengue-dbddan.pdf(diakses pada tanggal 08 Februari 2019 jam 21.12 WIB).

Tjokroprawiro. A., Setiawan. B., P., Effendi. C., Santoso. D., Soegiarto. G., (2015). Buku Ajar Ilmu Penyakit Dalam. Surabaya: Unair.

Tomia, A., Hadi, Kesumawati, U., Soviani S., Retnani, E. 2016. Kejadian Demam Berdarah Dengue (DBD) Berdasarkan Faktor Iklim di Kota Ternate Jurnal MKMI Vol.12 No. 4. https://media.neliti.com/media/publications/212955kejadian-demam-berdarah-dengue-dbd-berda.pdfEmail:

alga tte@yahoo.co.id(Diakses pada tanggal 08 Februari 2019 jam 22.00 WIB).

Wijaya, AS dan Putri, YM. 2013. KMB 2: Keperawatan Medikal Bedah 2. Yogyakarta: Nuha Medika. 